\title{
The [ $\left.{ }^{18} \mathrm{~F}\right] 2-\mathrm{Fluoro}-1,3-$ thiazolyl Moiety - an Easily-Accessible Structural Motif for Prospective Molecular Imaging Radiotracers
}

\author{
Fabrice G. Siméon, Matthew T. Wendahl, and Victor W. Pike \\ Molecular Imaging Branch, National Institute of Mental Health, National Institutes of Health, \\ Building 10, Rm. B3 C346A, 10 Center Drive, Bethesda, MD 20892-1003, USA
}

\begin{abstract}
2-Fluoro-1,3-thiazoles were rapidly and efficiently labeled with no-carrier-added fluorine-18 $\left(t_{1 / 2}\right.$ $=109.7 \mathrm{~min}$ ) by treatment of readily prepared 2-halo precursors with cyclotron-produced $\left[{ }^{18} \mathrm{~F}\right]$ fluoride ion. The $\left[{ }^{18} \mathrm{~F}\right] 2$-fluoro-1,3-thiazolyl moiety constitutes a new and easily-labeled structural motif for prospective molecular imaging radiotracers.
\end{abstract}

\section{Keywords}

Radiofluorination; 1,3-thiazole; microwave-assisted synthesis

\begin{abstract}
Interest in the efficient synthesis of new fluoro compounds as potential drugs and imaging agents is growing dramatically. ${ }^{1}$ Fluorinated drugs include antibiotics, sedatives, antidepressants and anti-tumor agents. ${ }^{1,2}$ Moreover, methods for introducing fluorine-18 $\left(t_{1 / 2}=109.7 \mathrm{~min}\right)$ into organic molecules have become increasingly important for the development of radiotracers for positron emission tomography (PET) ${ }^{3}$, a sensitive and powerful technique for molecular imaging in animal and human subjects in vivo, and hence for clinical research and diagnosis.4 For the development of PET radiotracers, the preferred source of fluorine-18 is $\left[{ }^{18} \mathrm{~F}\right]$ fluoride ion, obtained from the ${ }^{18} \mathrm{O}(\mathrm{p}, \mathrm{n}){ }^{18} \mathrm{~F}$ reaction on ${ }^{18} \mathrm{O}$ enriched water. ${ }^{5}$ This production method is very high yielding and importantly gives the $\left[{ }^{18}\right.$ F $]$ fluoride ion at a very high 'no-carrier-added' (NCA) specific radioactivity. High specific radioactivity (typically $>1 \mathrm{Ci} / \mu \mathrm{mol}$ ) is often mandatory for the safety and efficacy of PET radiotracers. ${ }^{6}$

The introduction of fluoride ion or $\left[{ }^{18} \mathrm{~F}\right]$ fluoride ion at an alkyl carbon is usually straightforward. ${ }^{6}$ Fluoroalkanes are however generally more susceptible to metabolic defluorination in vivo than fluoroarenes. ${ }^{7}$ Therefore, the latter are often more desirable targets in the development of drugs and of ${ }^{18} \mathrm{~F}$-labeled imaging agents. $\left[{ }^{18} \mathrm{~F}\right]$ Fluoride ion may be incorporated readily into electron-deficient benzenes ${ }^{6}$ and also into pyridines ${ }^{6,8}$ at their 2- and 4-positions by aromatic nucleophilic substitution reactions, and at all positions in electron-rich or electron-poor benzenes and pyridines by reaction with diaryliodonium salts. ${ }^{9}$ Fast efficient methods for utilizing $\left[{ }^{18}\right.$ F $]$ fluoride ion in the fluorination of other arenes, especially other heteroarenes, have however been little explored.
\end{abstract}

Publisher's Disclaimer: This is a PDF file of an unedited manuscript that has been accepted for publication. As a service to our customers we are providing this early version of the manuscript. The manuscript will undergo copyediting, typesetting, and review of the resulting proof before it is published in its final citable form. Please note that during the production process errors may be discovered which could affect the content, and all legal disclaimers that apply to the journal pertain.

Supplementary data: Experimental procedures, characterization data for new compounds 9-10, and representative radio-HPLC chromatograms for compounds $\left[{ }^{18} \mathrm{~F}\right] 7-\left[{ }^{18} \mathrm{~F}\right] \mathbf{1 0}$. 
1,3-Thiazole can be regarded as isosteric with benzene and pyridine. ${ }^{10}$ Replacement of a phenyl or pyridinyl group with a 1,3-thiazolyl group may therefore lead to an improved drug or receptor ligand. A striking example occurs among diarylacetylene-type metabotropic glutamate sub-type receptor 5 (mGluR5) ligands. Here pairing of a substituted 1,3-thiazolyl group with a substituted phenyl group in the diarylacetylene provides ligands with similar or higher potency than the pairing of other aryl groups. ${ }^{11}$ Such 1,3-thiazoles appear susceptible to metabolism by oxidative ring opening. 12 However, one report suggests that fluorination of a 1,3-thiazolyl group might lead to better resistance to metabolism in vivo.13 We hypothesized that the 2-position in 1,3-thiazoles would be an attractive site for facile incorporation of fluorine-18 from $\left[{ }^{18} \mathrm{~F}\right]$ fluoride ion and moreover might deliver a relatively metabolically stable $\left[{ }^{18} \mathrm{~F}\right] 2$-fluoro-1,3-thiazolyl structural motif.

In order to establish reaction conditions for the preparation of $\left[{ }^{18} \mathrm{~F}\right] 2$-fluorothiazoles, we first sought a simple method to prepare reference 2-fluorothiazoles. Among the few methods reported for preparing such fluoro compounds, including fluoro-dediazoniation ${ }^{14}$ or nucleophilic substitution ${ }^{15,16}$, nucleophilic substitution with fluoride ion in 2-halo-1,3thiazoles ${ }^{16}$ appeared attractive since the precursor halo compounds were quite accessible.

2-Bromo-1,3-thiazole (1) was submitted to fluorination with potassium fluoride and an equimolar amount of the cryptand, Kryptofix ${ }^{\circledR}$ 2.2.2 (K 2.2.2) or the crown ether 18crown-6, in various solvents (DMSO, MeCN or DMF) under microwave irradiation. We found that fluorination was almost quantitative after irradiation for 10 minutes at $150{ }^{\circ} \mathrm{C}(35$ $\mathrm{W}$ ) in DMSO. The conversion of 2-bromo-1,3-benzothiazole (2) into the corresponding 2fluoro derivative (8) also proceeded in very high yield under these conditions (Table 1).

We decided to test the generality of these microwave conditions for the rapid high-yield preparation of other 2-fluoro-thiazole derivatives. First we prepared the 2-chloro-, 2-bromoand 2-iodo-1,3-thiazolyl compounds, 3-5, ${ }^{17}$ as simple analogs of a potent mGluR5 ligand, namely 3-[(2-methyl-1,3-thiazol-4-yl)-ethynyl]-pyridine. ${ }^{18}$ These halo compounds were subjected to fluorination under the most effective conditions found for $\mathbf{2}$. The target fluoro derivative 9 was successfully isolated in high yield from the chloro (3) and bromo (4) precursors (Table 1). The yield of $\mathbf{9}$ from the iodo precursor $\mathbf{5}$ was however low (Table 1).

We also prepared the 2-bromo and $N$-Me derivative (6) of the powerful antibiotic, thiabendazole, as a precursor for fluorination (Scheme 1). Previous work has shown that thiabendazole retains high fungicidal and bactericidal activity after 2-halogenation ${ }^{19}$ (halo $=$ $\mathrm{Cl}$ or $\mathrm{Br}$ ) of the thiazolyl group or $\mathrm{N}$-methylation ${ }^{20}$ of the imidazolyl ring. Fluorination of 6 in DMSO for 10 min with microwave heating at $130{ }^{\circ} \mathrm{C}$ gave $\mathrm{N}$-methyl-2-

fluorothiabendazole (10) in good yield (Scheme 1; Table 1).

The apparent rapidity and effectiveness of the rapid fluorination of 2-halo-1,3-thiazoles with potassium fluoride under microwave irradiation encouraged us to explore the preparation of $\left[{ }^{18} \mathrm{~F}\right] 2$-fluoro-1,3-thiazoles with cyclotron-produced NCA $\left[{ }^{18} \mathrm{~F}\right]$ fluoride ion under thermal or microwave heating conditions (Table 2). We found that treatment of a low amount of the 2fluoro-thiazole $7(1.1 \mathrm{mg} ; 1.0 \mathrm{mmol})$ with $\left[{ }^{18} \mathrm{~F}\right]$ fluoride ion in the presence of $\mathrm{K}^{+}-\mathrm{K} 2.2 .2$ in acetonitrile $(500 \mu \mathrm{L})$ at $110{ }^{\circ} \mathrm{C}$ produced carrier-added $\left[{ }^{18} \mathrm{~F}\right] 7$ in $26 \%$ decay-corrected radiochemical yield (RCY) within $35 \mathrm{~min}$ (Scheme 2).

Similar treatment of the 2-bromo compound $\mathbf{1}$ in DMSO with NCA $\left[{ }^{18} \mathrm{~F}\right]$ fluoride ion at 150 ${ }^{\circ} \mathrm{C}$ for 30 min gave $\left[{ }^{18} \mathrm{~F}\right] 7$ in $29 \%$ RCY (Scheme 2). Use of microwave heating (10 min at $40-90 \mathrm{~W} ; 130^{\circ} \mathrm{C}$ ) dramatically increased the RCY of $\left[{ }^{18} \mathrm{~F}\right] 7$ to $81 \%$. Similarly, under thermal heating conditions, the RCY of $\left[{ }^{18} \mathrm{~F}\right] \mathbf{8}$ increased with temperature between 80 and $150{ }^{\circ} \mathrm{C}$, and with solvent polarity, among acetonitrile, DMF or DMSO. Thus, at $80^{\circ} \mathrm{C}$ in DMSO, $\left[{ }^{18} \mathrm{~F}\right] \mathbf{8}$ was obtained in only $26 \% \mathrm{RCY}$. A higher RCY of $\left[{ }^{18} \mathrm{~F}\right] \mathbf{8}(35 \%)$ was 
obtained in DMSO at $150{ }^{\circ} \mathrm{C}$ for 30 min. Under inert atmosphere in DMSO with brief microwave heating $\left(90 \mathrm{~W}, 150{ }^{\circ} \mathrm{C}, 10 \mathrm{~min}\right),\left[{ }^{18} \mathrm{~F}\right] \mathbf{8}$ was obtained in $47 \% \mathrm{RCY}$, and with a measured specific activity of $2.5 \mathrm{Ci} / \mu \mathrm{mol}$. Increase in temperature had less effect when using acetonitrile or DMF as solvent. In acetonitrile at 80 or $150{ }^{\circ} \mathrm{C}$ for $30 \mathrm{~min},\left[{ }^{18} \mathrm{~F}\right] \mathbf{8}$ was obtained in 19\% RCY, respectively. RCYs were similar in DMF under the same conditions. Thus, the 2-bromo-1,3-thiazoles $\mathbf{1}$ and $\mathbf{2}$ show reactivity towards radiofluoridation that is similar to that of 2-bromo-pyridine. ${ }^{21}$

The effect of halo leaving group on radiofluorination yield was examined with the 2-halothiazole precursors $3-5$. In one set of experiments, using a single batch of dry $\left[{ }^{18} \mathrm{~F}\right] \mathrm{F}^{-}-\mathrm{K}^{+}-\mathrm{K}$ 2.2.2 under identical reaction conditions (DMSO, $130{ }^{\circ} \mathrm{C}, 8 \mathrm{~min}, \mathrm{MW}$ ), $\left[{ }^{18} \mathrm{~F}\right] \mathbf{9}$ was obtained from $\mathbf{3}, \mathbf{4}$ and $\mathbf{5}$ in 14.5, 14 and 2.0\% RCY, respectively. This shows that chloro and bromo are the preferred halo leaving groups, as for halo-benzenes. ${ }^{6}$

The production of $\left[{ }^{18} \mathrm{~F}\right] \mathbf{9}$ from bromo precursor 4 was performed in DMSO under argon with microwave heating at $130{ }^{\circ} \mathrm{C}$ for $10 \mathrm{~min}$ and an improved $45 \% \mathrm{RCY}$ was obtained. Similarly, the bromo precursor 6 was radiofluorinated under microwave condition to give $\left[{ }^{18} \mathrm{~F}\right] \mathbf{1 0}$ in $23 \% \mathrm{RCY}$. Conditions for this later reaction were not optimized.

In conclusion, we developed a mild and operationally simple procedure for preparing 2fluoro-1,3-thiazoles in high yield by nucleophilic substitution with fluoride ion from readily prepared halo precursors under microwave irradiation. This procedure was successfully adapted to the rapid labeling of potential new radioligands with NCA $\left[{ }^{18} \mathrm{~F}\right]$ fluoride ion under thermal or microwave heating conditions for potential application in PET imaging. The generated 2-fluoro compounds are expected to show desirably high resistance to defluorination in vivo. Thus 2-fluoro-1,3-thiazolyl and $\left[{ }^{18} \mathrm{~F}\right] 2$-fluorothiazolyl moieties may now prove to be usefully new structural motifs for drugs and radioligands, respectively.

\section{Supplementary Material}

Refer to Web version on PubMed Central for supplementary material.

\section{Acknowledgments}

This work was supported by the Intramural Research Program of the National Institutes of Health (NIMH).

\section{REFERENCES}

1. Hagmann WK. J. Med. Chem 2008;51:4359-4369. [PubMed: 18570365]

2. Müller K, Faeh C, Diederich F. Science 2007;317:1881-1886. [PubMed: 17901324]

3. Phelps ME. Proc. Natl. Acad. Sci. USA 2000;97:9226-9233. [PubMed: 10922074]

4. a Watson DA, Su M, Teverovskiy G, Zhang Y, García FJ, Kinzel T, Buchwald SL. Science 2009;325:1661-1664. [PubMed: 19679769] b Furuya T, Kaiser HM, Ritter T. Angew. Chem., Int. Ed 2008;47:5993-5996.

5. a Ruth TJ, Wolf AP. Radiochim. Acta 1979;26:21-24. b Guillaume M, Luxen A, Nebeling B, Argentini M, Clark JC, Pike VW. Appl. Radiat. Isot 1991;42:749-762.

6. Cai L, Lu S, Pike VW. Eur. J. Org. Chem 2008;17:2853-2873.

7. Pike VW. TIPS 2009;30:431-440. [PubMed: 19616318]

8. a Dolci L, Dollé F, Jubeau S, Vaufrey F, Crouzel C. J. Label. Compd. Radiopharm 1999;42:975985.b Dollé, F. PET Chemistry - the Driving Force in Molecular Imaging. Schubiger, PA.; Lehman, L.; Friebe, M., editors. Springer; 2007. p. 114-157.Ch. 5

9. a Pike VW, Aigbirhio FI. J. Chem. Soc., Chem. Commun 1995:2215-2216. b Shah A, Pike VW, Widdowson DA. J. Chem. Soc., Perkin Trans I 1998:2043-2046. c Ross TL, Ermert J, Hocke C, Coenen HH. J. Am. Chem. Soc 2007;129:8018-8025. [PubMed: 17536798] d Carroll MA, Nairne J, 
Woodcraft JL. J. Labelled Compd. Radiopharm 2007;50:452-454. e Chun J-H, Lu S, Lee Y-S, Pike VW. J. Org. Chem 2010;75:3332-3338. [PubMed: 20361793]

10. Wermuth, CG., editor. The Practice of Medicinal Chemistry. 2nd Ed.. Academic Press; 2003.

11. a Slasssi A, Isaac M, Edwards L, Minindis A, Wensbo D, Mattson J, Nilsson K, Raboisson P, McLeod D, Stormann TM, Hammerland LG, Johnson E. Curr. Topics Med. Chem 2005;5:897911. b Siméon FG, Brown AK, Zoghbi SS, Patterson VM, Innis RB, Pike VW. J. Med. Chem 2007;50:3256-3266. [PubMed: 17571866]

12. Yang X, Chen W. Xenobiotica 2005;35:797-809. [PubMed: 16278192]

13. Briner PH, Fyfe MCT, Martin P, Murray PJ, Naud F, Procter MJ. Org. Process Res. Dev 2006;10:346-348.

14. a Grünert C, Wiechert K. Zeitsch. Chem 1970;10:188-189. b Lowe G, Potter BVL. J. Chem. Soc., Perkin Trans 1 1980:2026-2028. c Kim YH, Lee CH, Ki YC. Tetrahedron Lett 1990;31:30193022. d Yoneda N, Fukuhara T. Tetrahedron 1996;52:23-26. e Berger, R.; Chang, L.; Edmondson, SD.; Globe, SD.; Ha, SN.; Kar, NF.; Kopka, IE.; Li, B.; Morriello, GJ.; Moyes, CR.; Shen, D-M.; Wang, L.; Zhu, C. 2009. US Patent 253705 A1

15. Bartoli G, Latrofa A, Naso F, Todesco PE. J. Chem. Soc., Perkin Trans. 1 1972;21:2671.

16. a Gallagher PT, Iddon B, Suschitzky H. J. Chem. Soc., Perkin Trans. 1 1980:2358-2361. b Beck, G.; Schubert, R. 1988. US Patent 4,788,208 c Benoit, M.; Demoute, J-P.; Wehrey, C. 1993. Eur. Patent 0556123 A1 d Kim Y-H. Phosphorus, Sulfur, Silicon and the Related Elements 1993;74:249-260.

17. Siméon FG, Wendahl MT, Pike VW. J. Org. Chem 2009;74:2578-2581. [PubMed: 19231816]

18. Cosford NDP, Tehrani L, Roppe J, Schweiger E, Smith ND, Anderson J, Bristow L, Brodkin J, Jiang X, McDonald I, Rao S, Washburn M, Varney MA. J. Med. Chem 2003;46:204-206. [PubMed: 12519057]

19. a Guczoghy, L.; Puklics, M.; Toth, G.; Szabo, G.; Palfi, D. 1973. Fr. Patent 7230738 b Tashika, Y.; Ito, T.; Takanashi, K.; Ono, M. 1967. Jpn. Tokkyo Koho JP 19650309

20. Schiffmann R, Neugebauer A, Klein CD. J. Med. Chem 2006;49:511-222. [PubMed: 16420038]

21. a Greguric I, Taylor SR, Denoyer D, Ballantyne P, Berghofer P, Roselt P, Pham TQ, Mattner F, Bourdier T, Neels OC, Dorow DS, Loc'h C, Hicks RJ, Katsifis A. J. Med. Chem 2009;52:52995302. [PubMed: 19691348] b Dolci L, Valette H, Vaufrey F, Fuseau C, Bottlaender M, Crouzel C. Bioorg. Med. Chem 1999;7:467-479. [PubMed: 10220033] 


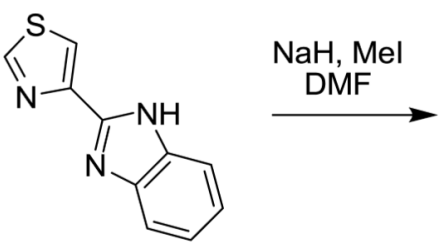

11

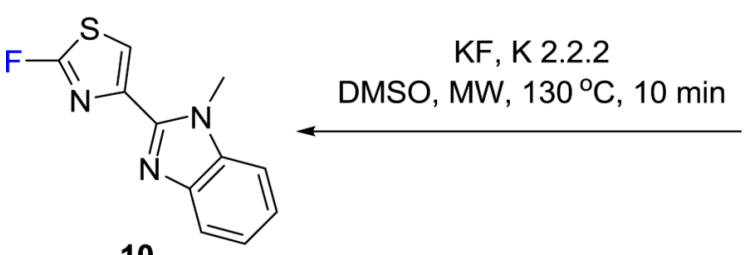

10

Scheme 1.

Synthesis of $N$-methyl-2-fluoro-thiabendazole (10).

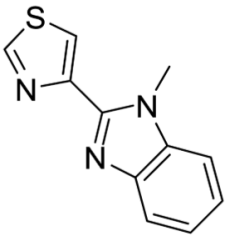

12

1) $\mathrm{BuLi}, \mathrm{Me}_{3} \mathrm{SnCl}$ 2) $\mathrm{Br}_{2}$

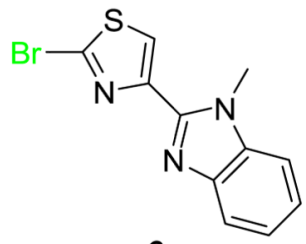

6 
Table 1

Yields of 2-fluorothiazoles produced under microwave irradiation.
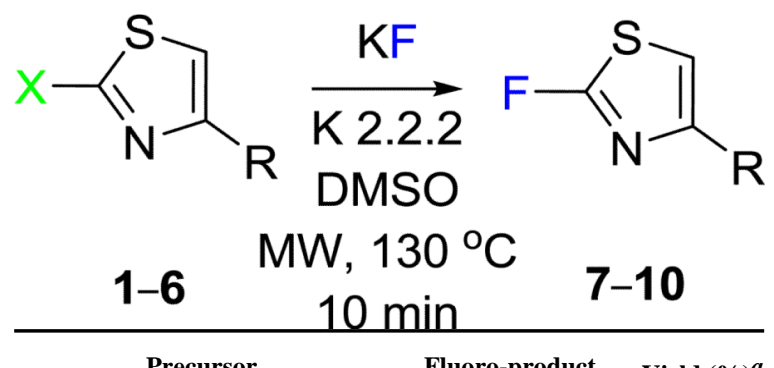

\begin{tabular}{llllll} 
& & Precursor & & Fluoro-product & Yield (\%) \\
\hline & $\mathbf{R}$ & $\mathbf{X}$ & & \\
\hline $\mathbf{1}$ & $\mathrm{H}$ & $\mathrm{Br}$ & $\mathbf{7}$ & 95 \\
$\mathbf{2}$ & & $\mathrm{Br}$ & $\mathbf{8}$ & 89
\end{tabular}

3<smiles>C/C=C\C=C/C</smiles>

$\mathrm{Cl} \quad 9$

4<smiles>CC#Cc1ccccc1</smiles>

$\mathrm{Br} \quad 9$

5

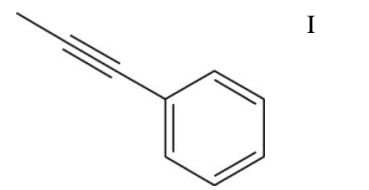

9

9

6

$\mathrm{Br} \quad \mathbf{1 0}$

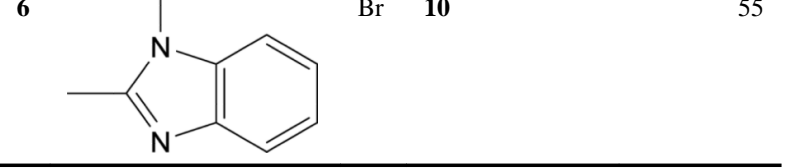

${ }^{a}$ Yield for isolated and analytically pure compound. 


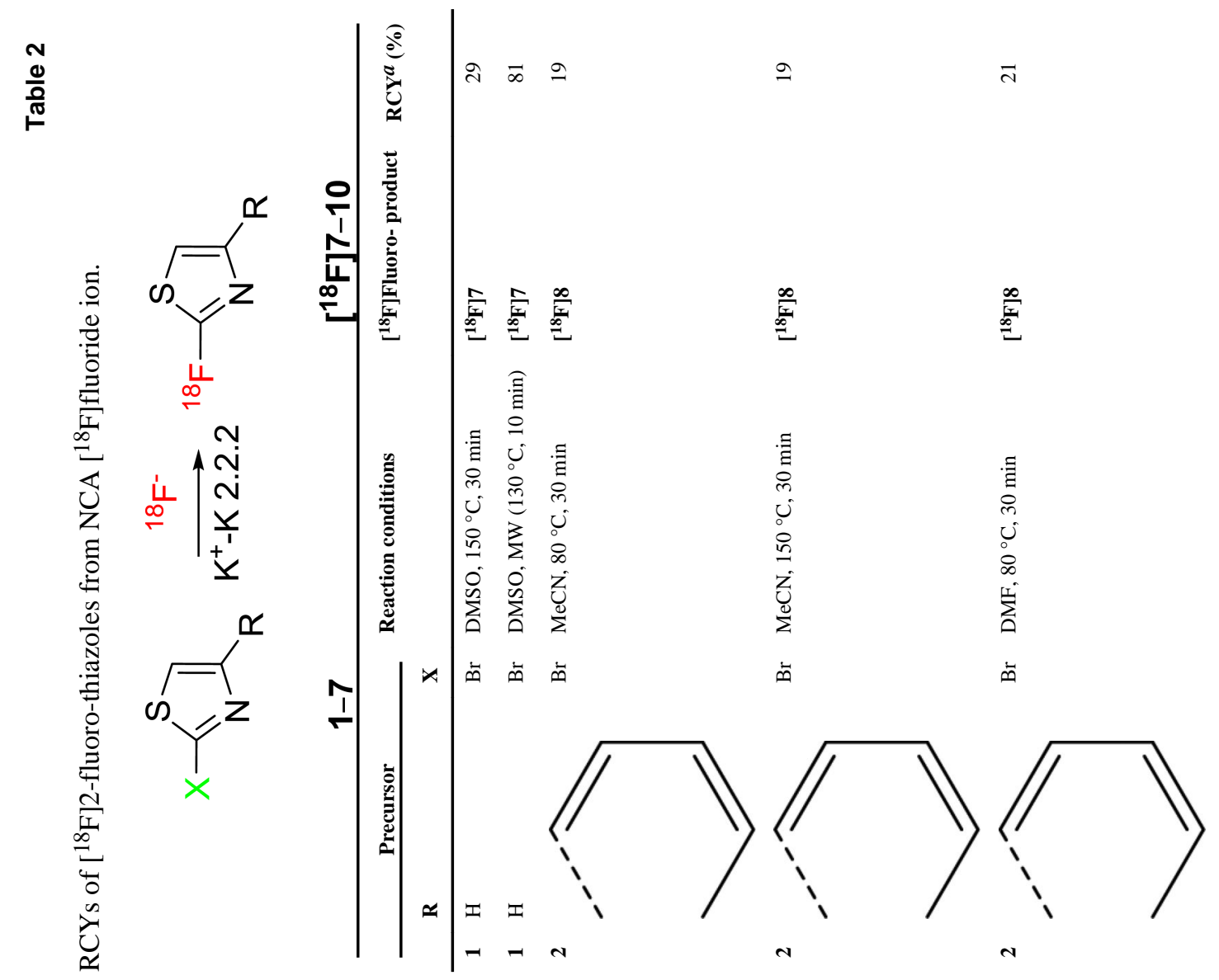




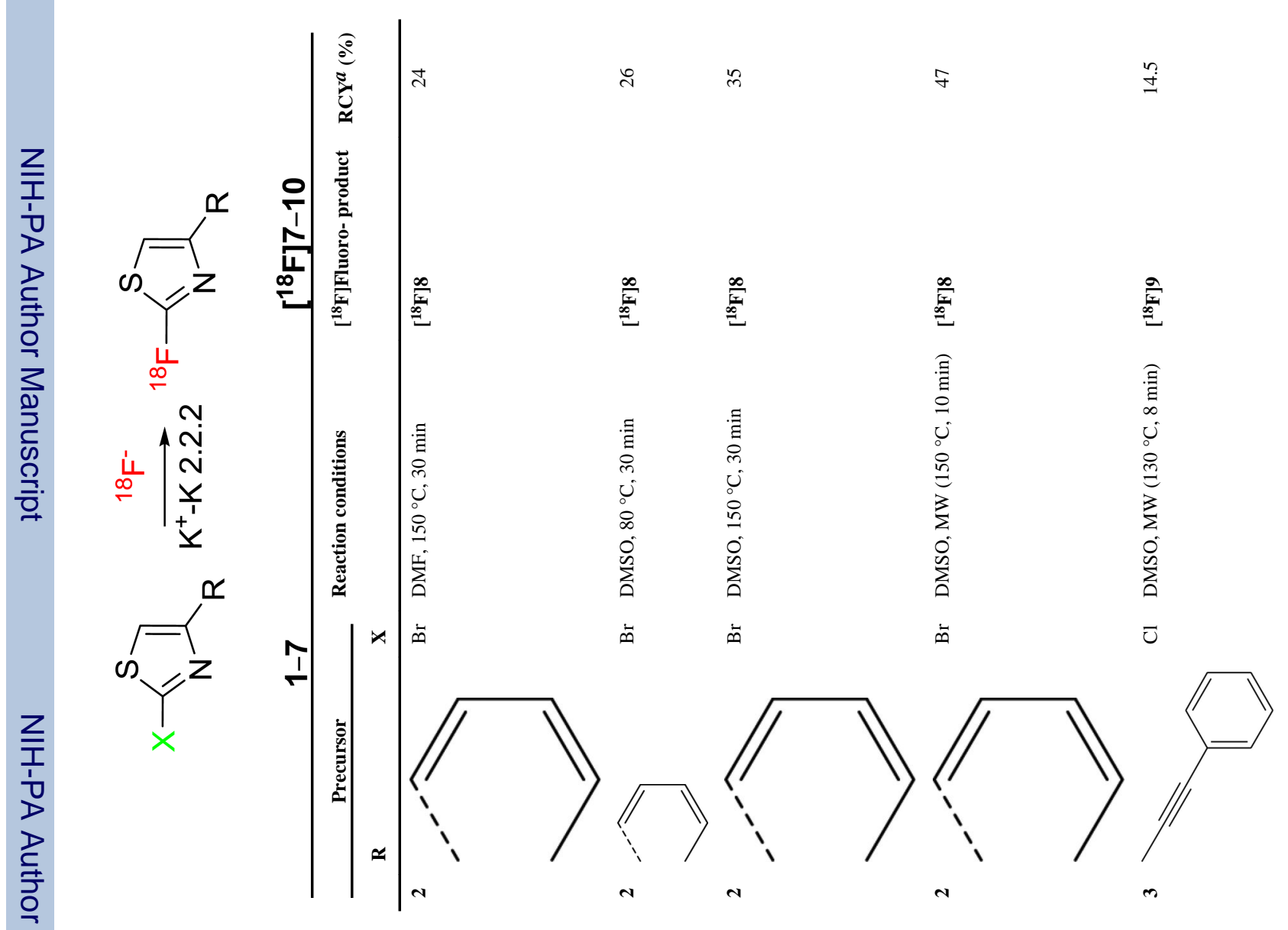




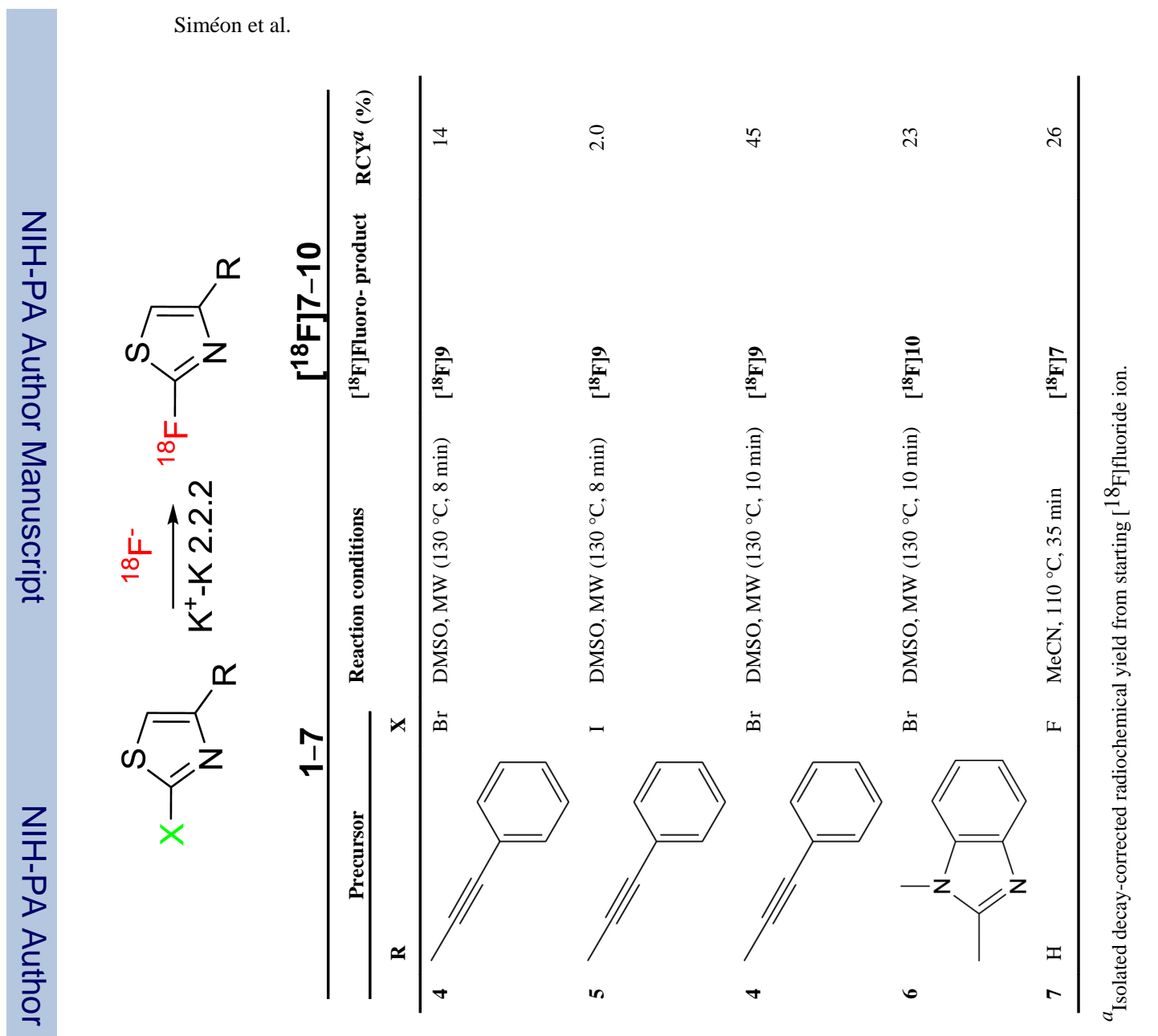

Tetrahedron Lett. Author manuscript; available in PMC 2011 November 17. 